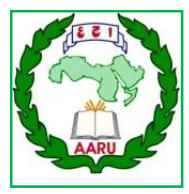

Arab Univ. J. Agric. Sci., Ain Shams Univ., Cairo, Egypt 28(1), 165-175, 2020

Website: http://ajs.journals.ekb.eg

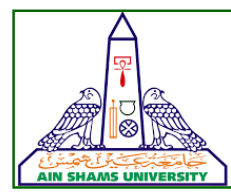

\title{
HYDRAULIC ASSESSMENT OF MEDIA FILTERS UTILIZING TREATED WASTEWATER FOR COTTON IRRIGATION
}

\author{
Heba $^{1 *}$ M.F. El-Waly, El-Gindy² A.M., El-Bagoury² K.F.T. \\ and Emera ${ }^{1}$ M.A.A.
}

1- Cotton Research Institute, Agricultural Research Center, Giza, Egypt.

2- Agric. Engineering Dept., Fac. of Agric., Ain Shams Univ., P.O. Box 68, Hadayek Shoubra 11241, Cairo, Egypt

*Corresponding author: hebaelwaly@gamil.com

Received 21 December, 2019

Accepted 9 February, 2020

\section{ABSTRACT}

The study were carried out at Sarapium Forest, Ministry of Agriculture and Land Reclamation in "Sarapium", Ismailia Governorate, Egypt, during 2018 and 2019 seasons to investigate the effect of media depth on the performance of different types of emitters for irrgating cotton (verity Giza 94) using treated wastewater. Also this study estimates the effect of using treated wastewater on the cotton growth, quantity and quality.

The first experiment design for filtration performance was a split-plot with four replications. The main plots involved two media filtration depths (50 $\mathrm{cm}$ and $70 \mathrm{~cm}$ ) and the sub-plots involved the time of operation $(0,25,50,75$ and $100 \mathrm{~h})$. While the second experiment design for planting cotton was a split-plot with three replications. The main plots involved two plant distribution (Mutual and Opposite) and the sub-plots involved the three types of emitters namely: online $4 \mathrm{l} / \mathrm{h}$ compensative, online $4 \mathrm{l} / \mathrm{h}$ non-compensative and built- in $4 \mathrm{l} / \mathrm{h}-30 \mathrm{~cm}$ non-compensative the distance between emitters were (30 $\mathrm{cm})$.

The results indicated that: Increasing media filtration depth from 50 to $70 \mathrm{~cm}$ has led to decrease the filtration flowrate with increasing pressure losses, biological oxygen demand $\left(\mathrm{BOD}_{5}\right)$ and total suspended solids (TSS). The filtration flowrate decreased by increasing operation time from 0 to 100 but pressure losses, $\mathrm{BOD}_{5}$ and TSS was increased. Emitters performance of online compensative and built-in non-compensative were generally better than the online non-compensative under using wastewater quality and emitters performance decrease by increasing operation time from zero to 100 hours. Plants distribution significantly effect on growth and yield components of cotton. Planting cotton by mutual method gave the highest values of number of opened bolls per plant, seed cotton yield (Ken./fed.). Using on-line compensative emitter gave the largest values of plant height, number of opened bolls per plant, boll weight and seed cotton yield (Ken./fed.). Mutual planting method and online compensative gave the highest values of number of friuting branches per plant, boll weight, number of opened bolls per plant, seed index and seed cotton (yield per fed.).

Keywords: Media filter, Treated wastewater, Drip irrigation, Cotton Growth and Yield.

\section{INTRODUCTION}

According to Ministry of Water Resources and Irrigation (MWRI), Egypt (2014) Agriculture expends a large amount of the obtainable water in Egypt, with its share exceeding $85 \%$ of the total demand for water. Utilizing treated wastewater represents a viable option. Capra and Scicolone (2007) stated that the performance of the emitters and filters depends on the quality of the wastewater; Total Suspended Solids (TSS) influence the percentage of totally clogged emitters, the mean discharge emitted, the emission uniformity, and the operating time of the filter between cleaning operations; no significant difference was observed between the same kind of emitter placed on soil or sub-soil; gravel media and disk filters assured better performance than screen filters. Keller and Bliesner 
(1990) categorized the total physical suspended solids (TSS) in irrigation water used in pressured irrigation system as follow: low when TSS $<50$ ppm medium 50-100 ppm, and high $>100$. El-Berry et al (2003) mentioned that the granulated media was more efficient in the removal qualification such as TSS $\mathrm{mg} / \mathrm{L}, \mathrm{BOD}_{5} \mathrm{mg} / \mathrm{L}$, with growing by percentages of $16.2,2.7$ respectively than those of the crushed one.

Shortage of irrigation water is an important problem in arid and semiarid regions. Therefore, the wastewater application in agriculture seems to be an indispensable solution. At the same time, Egypt produces approximately $3.65 \mathrm{BCM}$ of treated wastewater annually, $0.73 \mathrm{BCM}$ of which $(20 \%)$ are treated primary treatment, and $2.92 \mathrm{BCM}(80 \%)$ are treated secondary treatment (2030 strategic vision for treated wastewater in Egypt)

Mhaske (2016) decided that cotton (Gossypium hirsutum L.) crop when it was irrigated with treated sewage water (TSW) had better crop growth throughout the growing period. Cotton's seed yield was increased by $11.82 \%$ with treated sewage water. Mohamed et al (2000) decided that the Egyptian cotton cultivars could be yielding economically irrigated with drainage fresh water mixture. However, fresh/drainage water treatment significantly improved seed cotton (yield/fed.) by about $8.10-$ $21.80 \%$ in comparison with drainage water treatment.

Drip irrigation has been considered essential irrigation systems which should to be utilized in the latterly reclaimed sandy areas. This method increases crop production and save much water. Cotton as a long summer season growing crop needs considerable amounts of irrigation water because maintain its growth particularly during the long flowering and fruiting period and to build up enough assimilates for fiber development. Therefore, trials have been devoted to use drip irrigation under sandy soil conditions. Sampathkumar et al (2006) found that respectable excesses in seed cotton yield/fed. because of the use of drip irrigation and reported that drip irrigation resulted in a good crop growth and yield advantage within reason a constant moisture content preserved always in the root zone of the cotton crop by repeated irrigation at shorter periods

The suitable plant density with good distribution for cotton plant per feddan was bringing about higher yield, earlier ripeness and reduced cost of insect and weed control. The suitable spacing is one of the management pursuits that influence canopy light interception, ripeness and vegetative dry matter of the cotton plant. Obasi and Msaakpa (2005) reported that wider hill spacing raised no. of sympodia, open bolls, boll weight and seed cotton yield while, it reduced plant height. Hamed (2006) decided that increasing plant population produced the best values of the first fruiting branch node, no. of plants/fed and seed cotton yield/fed while, detraction population density led to a considerable increase in number of fruiting branches per plant, no. of open bolls per plant, boll weight and seed cotton yield per plant. El-Shahawy and Hamoda (2011) found that increasing hill spacing significantly excessed no. of sympodia per plant, no. of open bolls per plant, boll weight and seed cotton yield /fed. While plant height, first sympodial position and lint $\%$ decreased.

The purposes of this investigation were to survey the influence of media depth on the performance of various types of emitters for irrigating cotton, response of Egyptian cotton verity (Giza 94) using treated wastewater and to investigate the effect of utilizing treated wastewater on the cotton growth, quantity and quality.

\section{MATERIALS AND METHODS}

The study were carried out at Sarapium Forest, Ministry of Agriculture and Land Reclamation in "Sarapium", Ismailia Governorate, Egypt, during 2018 and 2019 seasons to investigate the effect of media depth on the performance of different types of emitters for irrigating cotton (verity Giza 94) using treated wastewater. Also this study estimates the effect of using treated wastewater on the cotton growth, quantity and quality. The first experiment design for filtration performance was a split-plot with four replications. The main plots involved two media filtration depths $(50 \mathrm{~cm}$ and $70 \mathrm{~cm})$ and the subplots involved the operation time $(0,25,50,75$ and 100h). While the second experiment design for planting cotton was a split-plot with three replications. The main plots involved two plant distribution (Mutual and Opposite) and the sub-plots involved the three types of emitters namely: online $4 \mathrm{l} / \mathrm{h}$ compensative, online $4 \mathrm{l} / \mathrm{h}$ non-compensative and builtin $4 \mathrm{l} / \mathrm{h}-30 \mathrm{~cm}$ non-compensative the distance between emitters were $(30 \mathrm{~cm})$. The hydraulic data were filtration flowrate and pressure losses. The measured data involved organic matter such as $\mathrm{BOD}_{5}(\mathrm{mg} / \mathrm{l})$ and physical matter TSS (mg/l). The values of some chemical and organic analysis of the treated wastewater as analysed in laboratory at Ismailia Wastewater Treatment Plant in "Sarapeum" are presented in Table (1). 


\section{for Cotton Irrigation}

Table 1. Some Chemical analysis of treated wastewater (secondary treatment)

\begin{tabular}{|c|c|c|c|c|c|c|c|c|c|}
\hline \multirow{2}{*}{ PH } & \multirow{2}{*}{$\begin{array}{c}\text { EC } \\
(\mathbf{d s} / \mathbf{m})\end{array}$} & \multicolumn{4}{|c|}{ Cations (meq/I) } & \multicolumn{4}{c|}{ Soluble Anions (meq/I) } \\
\cline { 3 - 10 } & & $\mathbf{C a}^{++}$ & $\mathbf{M g}^{++}$ & $\mathbf{N a}^{+}$ & $\mathbf{K}^{+}$ & $\mathbf{C O}_{3}{ }^{-}$ & $\mathbf{H C O}_{3}{ }^{-}$ & $\mathbf{S O}_{4}^{--}$ & CL $^{-}$ \\
\hline 7.83 & 2.16 & 7.56 & 5.37 & 12.03 & 0.96 & $\mathrm{~N} . \mathrm{D}$ & 8.3 & 7.23 & 7.7 \\
\hline
\end{tabular}

Table 2. Some organic and biological analysis of treated wastewater

\begin{tabular}{|c|c|c|c|c|c|}
\hline $\begin{array}{c}\text { BOD }_{5} \\
(\mathbf{m g} / \mathbf{l})\end{array}$ & TSS (mg/l) & VSS. (mg/l) & TDS (mg/l) & Chlor. A (mg/l) & $\begin{array}{c}\text { F.Coliform No/100 } \\
\text { ml }\end{array}$ \\
\hline 48.2 & 28.9 & 23.3 & 654 & 0.064 & 32.183 \\
\hline
\end{tabular}

(TDS): Total dissolved solids,

(Chlor. A): Chlorophyll,

(F.Coliform): Fical coliform.

Table 3. Technical Specifications of filtration unit

\begin{tabular}{|c|c|c|c|}
\hline \multicolumn{2}{|r|}{ Specifications } & Gravel filters & Disk filter \\
\hline \multirow{13}{*}{$\begin{array}{l}\text { Specifications of } \\
\text { filters }\end{array}$} & Number of filters. & 3 & 1 \\
\hline & Recommended maximum flow rate $\left(\mathrm{m}^{3} \mathrm{~h}^{-1}\right)$. & 18 & 30 \\
\hline & Maximum operating pressure (bar). & 10 & 5 \\
\hline & Filtration capacity $\left(\mathrm{m}^{3} \mathrm{~m}^{-2} \mathrm{~h}^{-1}\right)$. & 53.1 & - \\
\hline & Inlet and outlet diameters (inch). & 2 & 3 \\
\hline & Height (mm). & 1100 & 60 \\
\hline & Tank diameter (mm). & 500 & 25 \\
\hline & Wall Thickness (mm). & 5.0 & 3 \\
\hline & Thickness of media layers (mm). & 600 & - \\
\hline & Back washing diameter (inch). & 2 & - \\
\hline & Up drain types. & Cylindrical & - \\
\hline & Up drain diameter (inch). & 2 & - \\
\hline & Effective diameter of granular media (mm). & 1.0 & \\
\hline
\end{tabular}

The disk filter used with diameter 3 inch, 120 mesh and maximum flowrate $30 \mathrm{~m}^{3} \mathrm{~h}$ -

\section{Methods of calculation}

\section{-Emitter Exponent}

The emitter is the most important part of drip irrigation tubing. An emitter with a high degree of pressure compensating $(x=0)$ is technically possible. Although the ideal emitter has not yet been invented. Emitter flow rate may fluctuate as pressure along the lateral line varies due to friction, evaluation, and accidental restriction, resulting in a nonuniform water application (Braud and Soon, 1980). Emitter discharge rate is a function of operatingz pressure as described in the power law:

$q=k H^{x}$
Where:

$\mathrm{q}$ : emitter discharge rate, $\mathrm{l} / \mathrm{h}$.

$\mathrm{k}$ : emitter constant.

$\mathrm{h}$ : operating pressure (KPa), and $\mathrm{x}$ : emitter exponent.

For a fully laminar flow regime, emitters must be very sensitive to pressure head changes and the value of $x$ must be 1.0. This means that a pressure variation of $20.0 \%$ may result in $\pm 20.0 \%$ emitter flow rate variation. Most non-compensating emitters are always fully turbulent With an $\mathrm{x}$ level of about 0.5 , indicating that a pressure variation of approximately $10.0 \%$. Further, for compansating emitter pressure variation causes little discharge variation. Compensating emitter has an $\mathrm{x}$ level ranging from 0.1 to 0.4 . A typical pressure compensating emitter would have an $x$ level equal to 0 (Braud and Soon, 1980). Equation (1) was used to calculate the $x$ values in this study. 


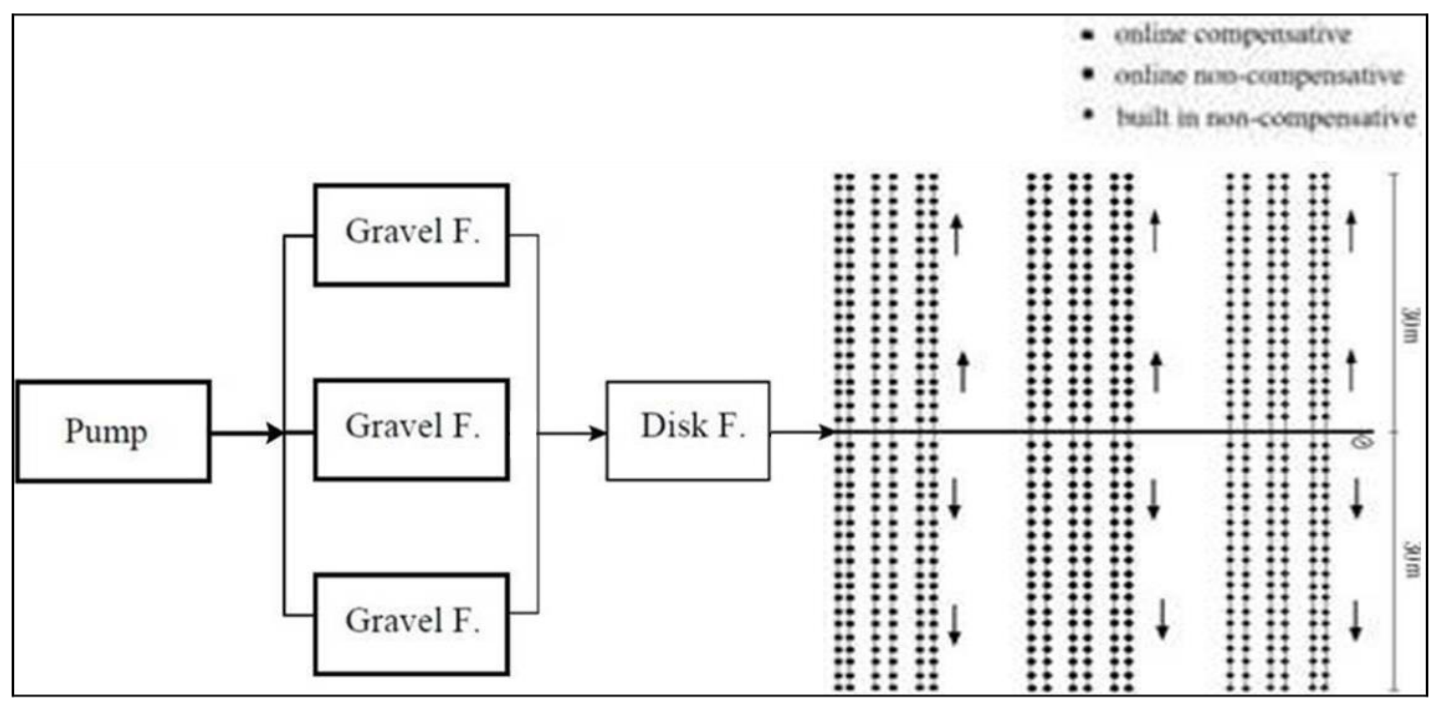

Fig. 1. Layout of experiment.

\section{-Emitter flow rate variation (qvar)} 1997).

Emitter flow rate variation (qvar) (Camp et al

$$
Q_{v a r}=\left(q_{m}-q_{n} / q_{n}\right) 100
$$

\section{Where:}

Qvar: variation of average flow rate from the nominal (\%).

$\mathrm{q}_{\mathrm{m}}$ : average flow rate, $(\mathrm{l} / \mathrm{h})$.

$q_{\mathrm{n}}$ : nominal flow rate at pressure of 1.0 bar and the same water temperature.

\section{-Manufacturer's variation (CVm).}

The manufacturer's coefficient of emitter's variation is a measurement of the variance of discharge of a random test of a production. Model and size of emitter as produced by the manufacturer and before any field operation or aging has taken place (ASAE 1996). The manufacturer's coefficient of emitter's variation $(\mathrm{CVm})$ is defined as follows:

$$
C V_{m}=S / q_{a}
$$

\section{Where:}

$\mathrm{CV}_{\mathrm{m}}$ : the manufacturer's coefficient of emitter's variation.

S: $\quad$ standard deviation of emitter discharges rates at a reference pressure head.

$\mathrm{q}_{\mathrm{a}}$ : average flow rate of emitters at that reference pressure head $\left(\mathrm{Ih}^{-1}\right)$.
The manufacturer's variation is predominantly bring out by pressure and heat instability during emitter production. In extension, a high $\mathrm{CV}_{\mathrm{m}}$ could happen because of a heterogeneous admixture of the materials used in the production of emitters. Typical values for $\mathrm{CV}_{\mathrm{m}}$ range from 2.0 to $15 \%$, although higher are possible (Boswell, 1985). Classification of $\left(\mathrm{CV}_{\mathrm{m}}\right)$ values according to ASAE standers are shown below in Table (4).

The emitter manufacture coefficient of variation "CVm" is one of the statistical terms, which can be used to show the trickle irrigation system uniformity. Numerous guidelines have been suggested for "CV", but those recommended by (ASAE, 1996) include:

\section{-Field emission uniformity coefficient, EU (\%).}

At the end of treatments the discharge of 16 emitters discharges within an irrigation block and is shown by equation (3) the treatment was measured to estimate the field emission uniformity coefficient, EU (\%) as follows :

$$
E U=(q m i n / q a) 100
$$

Where:

EU : the emission uniformity \%.

qmin: measured mean of the lowest $1 / 4$ of the emitter discharge $(1 / h)$.

$q_{a}:$ measured mean of all emitter discharge $(l / h)$. 
Table 4. ASAE recommended classification of emitter manufacture coefficient of variation "CVm"

\begin{tabular}{|c|c|c|c|c|c|}
\hline Classifications & Excellent & Average & Marginal & Poor & Unacceptable \\
\hline CVm (\%) & $<5.0$ & $5.0-7.0$ & $7.0-11.0$ & $11.0-15.0$ & $>15.0$ \\
\hline
\end{tabular}

The experiment layout included a flowmeter, two pressure gauges combined before and after each filter and twelve polyethylene lateral lines for each emitters. Lateral line was $30 \mathrm{~m}$ long and had 100 emitters attached at a spacing of $0.3 \mathrm{~m}$. The external diameters of the laterals were $16(\mathrm{~mm})$ with wall thickness $1.2(\mathrm{~mm})$, the system was operated for up to $100 \mathrm{~h}$. On each day of operation, the exact time of operation, the total flow volume 30 were recorded. Because the head loss in lateral lines was very small, the pressure along the lateral can be neglected.

The experiment for planting cotton was planted on April $17^{\text {th }}$ in 2019 season. Cotton plant thinned after complete emergence (35 day from planting) to two plants /hill. Standard agricultural practices were followed throughout the growing season. All samples were chosen random from each plot to study growth and yield traits. Soil samples were analysed before planting, according to Chapman and Pratt (1978). The results of the soil analysis are shown in Table (5).

Growth characters (plant height at harvest $(\mathrm{cm})$ and number of fruting branches/plant) were estmated. addationaly samples were randomly taken from each plot to determine number of open bolls per plant, boll weight gm, seed index gm, lint percentage (Lint \%) and seed cotton yield/fed.

Table 5. Soil mechanical and chemical analyses of the experimental sites in 2019 season

\begin{tabular}{|c|c|c|c|c|c|c|c|}
\hline \multicolumn{4}{|c|}{ Mechanical analysis: } & \multicolumn{4}{|c|}{ Chemical analysis: } \\
\hline $\begin{array}{l}\text { Sand } \\
(\%)\end{array}$ & $\begin{array}{l}\text { Silt } \\
(\%)\end{array}$ & $\begin{array}{l}\text { Clay } \\
\text { (\%) }\end{array}$ & $\begin{array}{l}\text { Textur } \\
\text { e class }\end{array}$ & $\mathrm{pH}$ & $\begin{array}{c}\text { E.C. } \\
\text { (m.moh) }\end{array}$ & $\begin{array}{c}\text { Organic } \\
\text { matter (\%) }\end{array}$ & Total CaCO3 (\%) \\
\hline 93.52 & 4.35 & 2.13 & Sandy & 7.85 & 2.08 & 0.21 & 1.50 \\
\hline \multicolumn{4}{|c|}{$\begin{array}{l}\text { Soluble anions concen. (meq/L) } \\
\text { (meq/100g soil) }\end{array}$} & \multicolumn{3}{|c|}{$\begin{array}{l}\text { Soluble cations concen. (meq/L) } \\
\text { (meq } / 100 \mathrm{~g} \text { soil) }\end{array}$} & \\
\hline $\mathrm{Na}^{+}$ & $\mathrm{K}^{+}$ & $\mathrm{Ca}^{++}$ & $\mathrm{Mg}^{++}$ & $\mathrm{CL}^{-}$ & $\mathrm{HCO}_{3}^{-}$ & $\mathrm{SO}_{4}^{-}$ & \\
\hline 46.44 & 0.51 & 18.20 & 15.52 & 11.50 & 1.45 & 1.50 & \\
\hline
\end{tabular}

\section{Statistical analysis}

Whole collected data were subjected to statsitical analysis as approached by Gomez and Gomez (1984) and means were compared by LSD at $5 \%$ level of probability.

\section{RESULTS AND DISCUSSION}

\section{Hydraulic chractaristes on media filter}

Data in Table (6) showed that filtration flow rate $\left(\mathrm{m}^{3} / \mathrm{h}\right)$ and pressure losses were significantly affected by media filtration depth, operation time and the interaction between them. Increasing media filtration depth from 50 to $70 \mathrm{~cm}$ the filtration flow rate was decreased and the pressure losses was increased. By increasing the operation times from 0 to 100 the filtration flow rate was decreased and the pressure losses was increased. The reduction of filtration flow rate for different media depth in filter and at start and end of the experiment during time of operation $100 \mathrm{~h}$. due to increasing for organic matters and chemical contents in the treated wastewater. El-Awady et al (2008) stated the filtration performance of the different types of media filter under two depth and different operating conditions, and noticed that there was an improvement of the removal efficiency due to increasing bed depth from 30 to 50 $\mathrm{cm}$.

\section{Water quality}

The characteristics of wastewater used to evaluate the filtration efficiency (biological oxygen demand $\left(\mathrm{BOD}_{5}\right)$ and total suspended solids (TSS)) during time of operation (h) up to 100 hours are shown in Table (7). The data showed that $\mathrm{BOD}_{5}$ and TSS were significantly affected by media filtration depth, operation time and the interaction between them. Increasing media filtration depth from 50 to $70 \mathrm{~cm}$ and operation time from zero to 100 gave 
Table 6. Effect of media filtration depth and operation time on filtration flowrate and pressure losses

\begin{tabular}{|c|c|c|c|c|c|c|c|c|c|c|c|c|}
\hline \multirow{3}{*}{$\begin{array}{c}\text { Treatments } \\
\text { Media } \\
\text { filtration } \\
\text { depth (A) }\end{array}$} & \multirow{2}{*}{\multicolumn{6}{|c|}{$\begin{array}{c}\text { Filtration flow rate }\left(\mathrm{m}^{3} / \mathrm{h}\right) \\
\text { Operation time }(\mathrm{B}) \\
\end{array}$}} & \multicolumn{6}{|c|}{ Pressure losses } \\
\hline & & & & & & & \multicolumn{5}{|c|}{ Operation time (B) } & \multirow[b]{2}{*}{ Mean } \\
\hline & 0 & 25 & 50 & 75 & 100 & Mean & 0 & 25 & 50 & 75 & 100 & \\
\hline $50 \mathrm{~cm}$ & 25.56 & 22.76 & 21.43 & 19.43 & 16.33 & 21.10 & 0.133 & 0.133 & 0.200 & 0.333 & 0.300 & 0.220 \\
\hline $70 \mathrm{~cm}$ & 20.16 & 18.43 & 16.48 & 15.53 & 13.73 & 16.87 & 0.167 & 0.167 & 0.233 & 0.467 & 0.333 & 0.273 \\
\hline Mean & 22.86 & 20.60 & 18.95 & 17.48 & 15.03 & & 0.150 & 0.150 & 0.217 & 0.400 & 0.317 & \\
\hline $\begin{array}{c}\text { LSD at } 0.05 \\
\text { for }\end{array}$ & \multicolumn{2}{|c|}{ A 0.23} & \multicolumn{2}{|c|}{ B 0.61} & $\mathrm{AxE}$ & 0.86 & \multicolumn{2}{|c|}{ A 0.67} & \multicolumn{2}{|c|}{ B 0.15} & \multicolumn{2}{|c|}{ AxB 0.21} \\
\hline
\end{tabular}

Table 7. The characteristics of wastewater used to evaluate the water quality due to (BOD5) and (TSS)

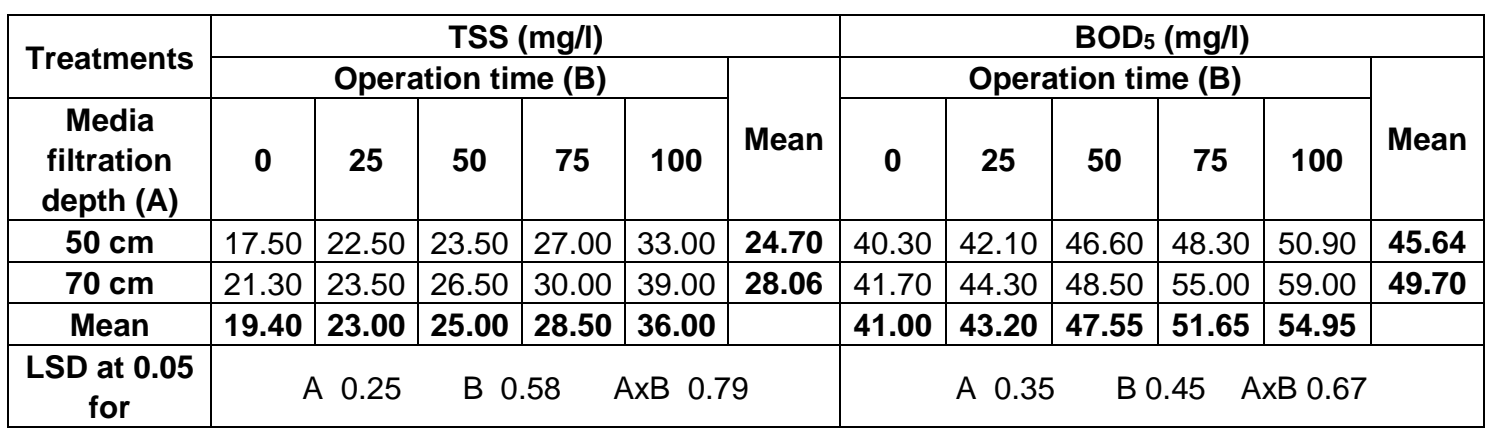

the highest values of $\mathrm{BOD}_{5}$ and TSS. The interaction between media filtration depth and operation time was significantly effect in $\mathrm{BOD}_{5}$ and TSS. 70 $\mathrm{cm}$ media filtration depth with $100 \mathrm{~h}$ operation time gave the highest values of $\mathrm{BOD}_{5}$ and TSS.

\section{Calibration of used drippers}

Data shown in Fig. (2) showed that when the pressure increases, the dripper flow rates increase. The laboratory experiments were conducted for three types of drippers (online compensative drippers, online non-compensative and built-in drip line), with nominal flow rates about $(4 \mathrm{l} / \mathrm{h})$, and gives the dripper flow-pressure functions as well as the regression equations.

Influence of wastewater on emitters performance

Data in Table (8) showed that great impact of the treated wastewater quality on the behaviour of different type emitters (online $4 \mathrm{l} / \mathrm{h}$ compensative, online $4 \mathrm{l} / \mathrm{h}$ non-compensative and built-in $4 \mathrm{l} / \mathrm{h}$ $30 \mathrm{~cm}$ non-compensative). Emitters performance of online compensative and built-in non-compensative were generally better than the online emitter noncompensative. The online emitter non-compensative with a similar discharge were more sensitive to clogging than inline emitter compensative and built in non-compensative when the total suspended solids and organic matter content increased. Data also in the same table showed that the emitters on and in pipes with a smaller diameter were sensitive to clogging by increasing operation time from 0 to 100 h. El-Tantawy et al (2009) found that on-line emitter is perfectable than in-line emitters. Inline emitters were more sensitive to clogging than on-line in partial and total percentages of emitters clogging.

\section{Determination of irrigation water requirements}

The irrigation water requirements were resolved along the season, by using weather data, spring from the standard FAO-penman method explained in (Allen et al 1998). The daily references evapotranspiration (ETo) was received from Central Lab. for Agricultural Climate. The crop coefficient factor $\left(\mathrm{k}_{\mathrm{c}}\right)$ as showed in Table (9). 


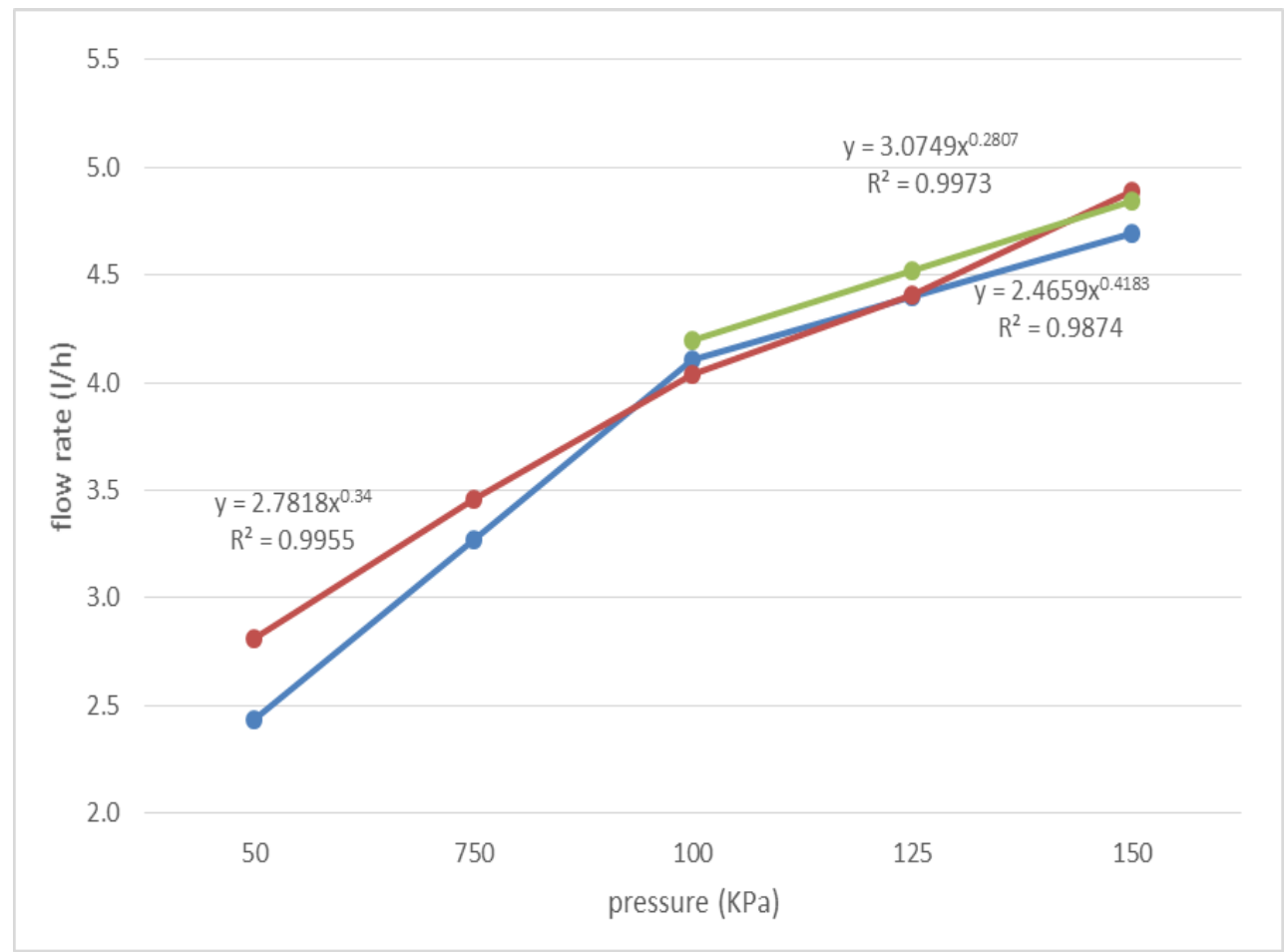

Fig. 2. Performance curves of tested dripper with flow rate $(4 \mathrm{l} / \mathrm{h})$.

Table 8. Hydraulic characteristics for different dripper under investigation under operating pressure (125 $\mathrm{KPa})$

\begin{tabular}{|c|c|c|c|c|c|}
\hline $\begin{array}{l}\text { Operation } \\
\text { Time }(h)\end{array}$ & Type of emitter & $\begin{array}{l}\text { Flow rate } \\
\quad(\mathrm{I} / \mathrm{h})\end{array}$ & $\begin{array}{c}\text { *Manufacture's } \\
\text { coefficient of } \\
\text { variation }\left(\mathrm{CV}_{\mathrm{m}}\right. \\
\%)\end{array}$ & $\begin{array}{l}\text { *Distribution } \\
\text { Uniformity } \\
\text { (DU \%). }\end{array}$ & $\begin{array}{l}\text { *Dripper flow } \\
\text { Variation } \\
\left(q_{\text {var }} \%\right)\end{array}$ \\
\hline \multirow{3}{*}{ Oh } & $\begin{array}{l}\text { Online } 4 \mathrm{I} / \mathrm{h} \\
\text { Compensative }\end{array}$ & 4.34 & $\begin{array}{c}2.52 \\
\text { Excellent }\end{array}$ & $\begin{array}{c}96.86 \\
\text { Excellent }\end{array}$ & $\begin{array}{c}11.39 \\
\text { Acceptable }\end{array}$ \\
\hline & $\begin{array}{c}\text { Online } 4 \mathrm{I} / \mathrm{h} \\
\text { Non-compensative }\end{array}$ & 3.93 & $\begin{array}{c}6.93 \\
\text { Average }\end{array}$ & $\begin{array}{l}89.3 \\
\text { Good }\end{array}$ & $\begin{array}{c}21.6 \\
\text { Unacceptable }\end{array}$ \\
\hline & $\begin{array}{l}\text { Built-in } 4 \mathrm{l} / \mathrm{h}-30 \mathrm{~cm} \\
\text { Non-compensative }\end{array}$ & 4.51 & $\begin{array}{c}3.5 \\
\text { Excellent } \\
\end{array}$ & $\begin{array}{c}95.0 \\
\text { Excellent }\end{array}$ & $\begin{array}{c}12.13 \\
\text { Acceptable }\end{array}$ \\
\hline \multirow{3}{*}{$50 \mathrm{~h}$} & $\begin{array}{c}\text { Online } 4 \mathrm{I} / \mathrm{h} \\
\text { Compensative }\end{array}$ & 4.12 & $\begin{array}{c}4.5 \\
\text { Excellent }\end{array}$ & $\begin{array}{c}94.07 \\
\text { Excellent }\end{array}$ & $\begin{array}{c}17.65 \\
\text { Acceptable }\end{array}$ \\
\hline & $\begin{array}{c}\text { Online } 4 \mathrm{l} / \mathrm{h} \\
\text { Non-compensative }\end{array}$ & 3.74 & $\begin{array}{c}7.19 \\
\text { Marginal } \\
\end{array}$ & $\begin{array}{l}89.97 \\
\text { Good }\end{array}$ & $\begin{array}{c}20.7 \\
\text { Unacceptable } \\
\end{array}$ \\
\hline & $\begin{array}{l}\text { Built-in } 4 \mathrm{l} / \mathrm{h}-30 \mathrm{~cm} \\
\text { Non-compensative }\end{array}$ & 4.10 & $\begin{array}{c}3.5 \\
\text { Excellent } \\
\end{array}$ & $\begin{array}{c}90.12 \\
\text { Excellent } \\
\end{array}$ & $\begin{array}{c}11.78 \\
\text { Acceptable } \\
\end{array}$ \\
\hline \multirow{3}{*}{$100 h$} & $\begin{array}{c}\text { Online } 4 \mathrm{l} / \mathrm{h} \\
\text { Compensative }\end{array}$ & 3.62 & $\begin{array}{c}3.4 \\
\text { Excellent }\end{array}$ & $\begin{array}{c}96.14 \\
\text { Excellent }\end{array}$ & $\begin{array}{c}12.37 \\
\text { Acceptable }\end{array}$ \\
\hline & $\begin{array}{c}\text { Online } 4 \mathrm{I} / \mathrm{h} \\
\text { Non-compensative }\end{array}$ & 3.23 & $\begin{array}{c}7.85 \\
\text { Marginal }\end{array}$ & $\begin{array}{l}89.75 \\
\text { Good }\end{array}$ & $\begin{array}{c}25.3 \\
\text { Unacceptable }\end{array}$ \\
\hline & $\begin{array}{l}\text { Built-in } 4 \mathrm{l} / \mathrm{h}-30 \mathrm{~cm} \\
\text { Non-compensative }\end{array}$ & 3.30 & $\begin{array}{c}7.05 \\
\text { Average }\end{array}$ & $\begin{array}{l}89.77 \\
\text { Good }\end{array}$ & $\begin{array}{c}22.96 \\
\text { Unacceptable }\end{array}$ \\
\hline
\end{tabular}


Table 9. The standard crop coefficient $(\mathrm{kc})$ for cotton crop in Mediterranean climate, at the crop growth stages

\begin{tabular}{|c|c|c|}
\hline Stage & $\begin{array}{c}\text { Duration of } \\
\text { the stages } \\
\text { (days) }\end{array}$ & KC \\
\hline Initial & 30 & 0.45 \\
\hline Development & 50 & 0.75 \\
\hline Mid-season & 55 & 1.15 \\
\hline Late season & 45 & 0.75 \\
\hline Total & 185 & \\
\hline
\end{tabular}

Water requirements of cotton plants $\left(E T_{c}\right)$ for the growing season were determined according to the following equation (Allen et al 1998).

$$
E T_{c}=E T o \times k_{c}
$$

Where:

ETc : the crop water requirement ( $\mathrm{mm} /$ day).

ETo : the crop coefficient.

$\mathrm{Kc}$ : the reference evapotranspiration ( $\mathrm{mm} /$ day).

Table 10. Determination of irrigation water requirements for cotton

\begin{tabular}{|c|c|c|c|c|c|c|c|c|c|c|}
\hline Month & April & \multicolumn{2}{|c|}{ May } & June & \multicolumn{2}{|c|}{ July } & Aug. & Sep. & \multicolumn{2}{|c|}{ October } \\
\hline $\mathrm{ET}_{\circ}$ (mm/day) & 3.5 & \multicolumn{2}{|c|}{4.7} & 4.6 & \multicolumn{2}{|c|}{4.3} & 3.5 & 3 & \multicolumn{2}{|c|}{2.2} \\
\hline $\begin{array}{c}E T_{c} \\
\text { (mm/day) }\end{array}$ & 1.575 & 2.115 & 3.525 & 3.45 & 4.945 & 4.025 & 4.025 & 2.25 & 2.25 & 1.65 \\
\hline $\begin{array}{c}E T_{c} \\
\left(m^{3} / \text { day/fed. }\right)\end{array}$ & 6.615 & 8.883 & 14.805 & 14.49 & 20.769 & 16.905 & 16.905 & 9.45 & 9.45 & 6.93 \\
\hline $\begin{array}{c}\mathrm{ET}_{\mathrm{c}} \\
\left(\mathrm{m}^{3} / \mathrm{fed} / \mathrm{month}\right)\end{array}$ & 99.225 & 133.245 & 222.075 & 434.7 & 145.383 & 388.815 & 507.15 & 18.9 & 264.6 & 103.95 \\
\hline $\begin{array}{c}E T_{c} \\
\left(m^{3} / \text { fed./growth }\right. \\
\text { stage) }\end{array}$ & \multicolumn{2}{|c|}{232.47} & \multicolumn{3}{|c|}{802.158} & \multicolumn{3}{|c|}{914.865} & \multicolumn{2}{|c|}{368.55} \\
\hline $\begin{array}{l}\mathrm{ET}_{\mathrm{c}} \text { ( } \mathrm{m}^{3} / \mathrm{fed} . / \\
\text { season) }\end{array}$ & \multicolumn{10}{|c|}{2318.043} \\
\hline
\end{tabular}

\section{Effect of plants distribution and emitter types as well as their interaction on cotton}

Data in Table (11) showed that plant height at harvest, number of fruiting branches per plant, number of opened bolls per plant, boll weight, seed cotton yield (Ken./fed.), lint \% and seed index were significantly affected by plants distribution. Planting cotton by mutual method gave the highest values of no. of fruiting branches/plant no. of opened bolls/plant, boll weight, seed cotton yield (Ken./fed.), and seed index while gave the lowest values of plant height at harvest and lint \% compared with the opposite method of planting cotton. The increase in growth and yield due to good plants distribution by using mutual planting method may be due to good water destruction and light and decreased humidity and insects. These results are in accordance with those obtained by Obasi and Msaakpa (2005) and El-Shahawy and Hamoda (2011). Data also in Table (9) showed that plant height at harvest, no. of fruiting branches /plant, no. of opened bolls/plant, boll weight, seed cotton yield (Ken./fed.), lint \% and seed index were significantly affected by emitter types. Using online compensative emitter gave the highest values of plant height, number of fruiting branches per plant, number of opened bolls per plant, boll weight, seed cotton yield (Ken./fed.), and seed index while gave the lowest values of lint \% compared with the other types of emitters, followed by built in non compensative emitter while the online non compensative emitter came the last. These results are in accordance with those obtained by. Sampathkumar et al (2006) reported significant 

for Cotton Irrigation

increases in seed cotton (yield/fed.) due to the use of drip irrigation. Also, reported that drip irrigation showed a good crop growth and yield advantage because of a stable moisture content maintained in the root zone of the cotton crop by frequent irrigation at shorter intervals. El-Tantawy et al (2009) found that online emitter is better than inline emitters. Inline emitters were more sensitive to clogging than online in partial and total percentages of emitters clogging.
Significant interaction occurred between plants distribution and emitter types for most studied characteristics Table (9). Mutual planting method and Online $4 \mathrm{I} / \mathrm{h}$ consumptive gave the highest values of no. of fruiting branches /plant, no. of opened bolls/plant, boll weight, seed index and seed cotton (yield/fed.).

Table 11. Growth attributes and yield and yield components as affected by plants distribution and Emitter types as well as their interaction

\begin{tabular}{|c|c|c|c|c|c|c|c|c|}
\hline \multicolumn{2}{|c|}{ Treatments } & \multicolumn{2}{|c|}{ Growth attributes } & \multicolumn{5}{|c|}{ yield and yield components } \\
\hline $\begin{array}{c}\text { Plants } \\
\text { distribution } \\
\text { (A) }\end{array}$ & Emitter types (B) & $\begin{array}{l}\text { Plant } \\
\text { height } \\
\text { at } \\
\text { harvest } \\
\text { (cm) }\end{array}$ & $\begin{array}{c}\text { No. of } \\
\text { fruiting } \\
\text { branches } \\
\text { /plant }\end{array}$ & $\begin{array}{c}\text { No. of } \\
\text { opened } \\
\text { bolls/plant }\end{array}$ & $\begin{array}{c}\text { Boll } \\
\text { weight } \\
\text { (g) }\end{array}$ & $\begin{array}{l}\text { Seed } \\
\text { cotton } \\
\text { yield } \\
\text { (Kentar/ } \\
\text { fed.) }\end{array}$ & $\begin{array}{l}\text { Lint } \\
(\%)\end{array}$ & $\begin{array}{c}\text { Seed } \\
\text { index } \\
(g)\end{array}$ \\
\hline \multirow{3}{*}{ Mutual } & $\begin{array}{c}\text { Online } 4 \mathrm{I} / \mathrm{h} \\
\text { compensative }\end{array}$ & 147.94 & 17.57 & 16.17 & 2.29 & 8.68 & 38.03 & 9.03 \\
\hline & $\begin{array}{l}\text { Online } 4 \mathrm{I} / \mathrm{h} \text { non } \\
\text { compensative }\end{array}$ & 142.33 & 16.69 & 14.90 & 2.19 & 8.14 & 38.88 & 8.79 \\
\hline & $\begin{array}{l}\text { Built-in } 4 \mathrm{I} / \mathrm{h} \text { non } \\
\text { compensative }\end{array}$ & 146.41 & 17.14 & 15.43 & 2.20 & 8.38 & 38.20 & 8.85 \\
\hline \multicolumn{2}{|c|}{ Mean } & 145.56 & 17.13 & 15.50 & 2.32 & 8.40 & 38.26 & 8.89 \\
\hline \multirow{3}{*}{ Opposite } & $\begin{array}{c}\text { Online } 4 \mathrm{I} / \mathrm{h} \\
\text { compensative }\end{array}$ & 157.12 & 15.80 & 14.22 & 2.21 & 7.82 & 38.30 & 8.78 \\
\hline & $\begin{array}{l}\text { Online } 4 \mathrm{I} / \mathrm{h} \text { non } \\
\text { compensative }\end{array}$ & 151.21 & 15.10 & 14.00 & 2.11 & 7.30 & 39.14 & 8.58 \\
\hline & $\begin{array}{l}\text { Built-in } 4 \mathrm{l} / \mathrm{h} \text { non } \\
\text { compensative }\end{array}$ & 153.30 & 15.32 & 14.44 & 2.14 & 7.62 & 38.67 & 8.70 \\
\hline \multicolumn{2}{|c|}{ Mean } & 153.87 & 15.41 & 14.22 & 2.16 & 7.58 & 38.70 & 8.69 \\
\hline \multirow{3}{*}{$\begin{array}{c}\text { General } \\
\text { mean of }(B)\end{array}$} & $\begin{array}{c}\text { Online } 4 \mathrm{I} / \mathrm{h} \\
\text { compensative }\end{array}$ & 152.53 & 16.68 & 15.20 & 2.25 & 8.25 & 38.17 & 8.91 \\
\hline & $\begin{array}{l}\text { Online } 4 \mathrm{I} / \mathrm{h} \text { non } \\
\text { compensative }\end{array}$ & 146.77 & 15.89 & 14.45 & 2.15 & 7.72 & 38.85 & 8.68 \\
\hline & $\begin{array}{l}\text { Built-in } 4 \mathrm{I} / \mathrm{h} \text { non } \\
\text { compensative }\end{array}$ & 149.86 & 16.23 & 14.94 & 2.17 & 8.00 & 38.43 & 8.78 \\
\hline \multirow{3}{*}{$\begin{array}{c}\text { LSD at } 0.05 \\
\text { for }\end{array}$} & A & 0.80 & 0.11 & 0.31 & 0.05 & 0.09 & 0.05 & 0.09 \\
\hline & B & 0.36 & 0.07 & 0.14 & 0.02 & 0.03 & 0.03 & 0.05 \\
\hline & $A \times B$ & 0.60 & 0.11 & 0.20 & N.S & 0.04 & 0.05 & 0.07 \\
\hline
\end{tabular}

\section{REFERENCES}

Allen R.G., Pereira L.S., Raes D. and Smith M. 1998. Crop evapotranspiration: guide-lines for computing crop water requirements. In: Proceedings of the Irrigation and Drainage Paper No. 56. Food and Agricultural Organization, United $\mathrm{Na}$ tions, Rome, Italy, pp. 2-3.
ASAE Standards 1996. EP458. Field evaluation of micro-irrigation systems. ASAE. Standards, $43^{\text {rd }}$ Edition, ASAE, St. Joseph, pp. 756-761.

Boswell, M. J. (1985). Design characteristics of line source drip tubes. Proc. of the 3rd Int. Drip/Trickle Irr. Cong., Ca., USA., pp. 306 - 312. 
Braud H.J. and Soon A.M. 1980. Trickle irrigation design for improved application uniformity. ASAE and CSAE Mtg. on trickle (drip) Irrigation Winnipeg, Canada, pp. 2571-2579.

Camp C.R., Sadlerand E.J. and Busscher W.J. 1997. A comparison of uniformity measure for drip irrigation systems. Trans Am. Soc. of Ag. Eng. 40(4), 1013-1020.

Capra A. and Scicolone B. 2007. Recycling of poor quality urban wastewater by drip irrigation systems. (Water management in coastal zones and deltas). J. of Cleaner Production. 15(16), 15291534.

Chapman H.D. and Pratt P.P. 1978. Methods of analysis for soils, plants and water. Univ. of California, Div. of Agric. Sci., Priced Publ. 4030, 1219.

El-Awady M.N., El-Berry A.M., Genaidy M.A.I. and Zayton A.M. 2008. Hydraulic properties effect of filter media on emitter clogging problems. Misr J. Ag. Eng., 25(3), 824-836.

El-Berry A.M., El-Tantawy M.T., Ghazy A.I. and Wasef E. 2003. Use of foam Media for filtering heavy sediments water. Egypt .J. of Ag. Res., 81(4), 1931-1945.

El-Shahawy, M.I.M. and Hamoda S.A.F. 2011. The proper agricultural management practices four the new promising hybrid cotton (Giza $77 \mathrm{x}$ Pima S6). J. Plant Production, Mansoura Univ., Mansoura, Egypt, 2, 1551-1561

El-Tantawy M.T., Matter M.A. and Arafa Y.E. 2009. Filters and emitters performance under treated wastewater. Misr J. Ag. Eng., 26(2), 886- 904.
Gomez K.A. and Gomez A.A. 1984. Statistical procedures for agriculture research. $2^{\text {nd }}$ Ed., John Willey and Sons, New York, USA, pp. 139-144.

Hamed F.S. 2006. Response of cotton cultivar Giza- 90 to population density and nitrogen levels. Assuit J. of Agric. Sci. 37(3), 173-184.

Keller J. and Bliesner R.D. 1990. Sprinkle and Trickle Irrigation. AVI Book, New York, USA, 652 p.

Mhaske A.R. 2016. Effect of treated domestic sewage water irrigation on yield and uptake of heavy metals in cotton - a case study from Nagpur city, Central India. Agropedology, 26(1), 34-39.

Ministry of Water Resources and Irrigation 2014. Water Scarcity in Egypt: The Urgent Need for Regional Cooperation among the Nile Basin Countries, pp. 1-5.

Mohamed M.E., Abou-Zaid M.K. and Aboushal A.A. 2000. Soil properties and cotton crop performance as affected by drainage eater re-use. Adv. in Agric. Res., 5(1), 1217-1234.

Obasi, M.O. and Msaakpa T.S. 2005. Influence of topping, side branch pruning and hill spacing on growth and development of cotton (Gossypium barbadense, L.) in the Southern Guinea Savanna location of Nigeria. J. of Agric. and Rural Development in the Tropics and Subtropics, 106(2), 155-165.

Sampathkumar T., Krishnasamy S., Ramesh S., Prabukumar G. and Gobi R. 2006. Growth, Nutrient Uptake and Seed Cotton Yield of Summer Cotton as Influenced by Drip, Surface Irrigation Methods and Mulching Practices Research. J. of Agric. and Biological Sci., 2(6), 420-422. 


$$
\begin{aligned}
& \text { هبه محمد فريد الوالي 1" - عبدالغنى محمد الجندي2 - خالد فران طاهر الباجوري2 - }
\end{aligned}
$$

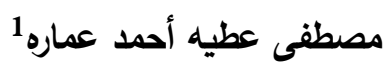

$$
\begin{aligned}
& \text { 1- معهد بحوث القطن - مركز البحوث الزراعية - الجيزة - مصر عطيه } \\
& \text { 2- قسم الهندسة الزراعية - كلية الزراعة - جامعة عين شمس - صعرب لبع } 68 \text { - حدائق شبرا } 11241 \text { - القاهرة - مصر }
\end{aligned}
$$

*Corresponding author: hebaelwaly@gamil.com

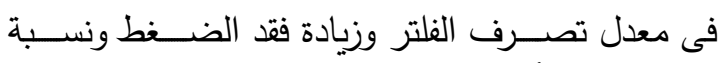

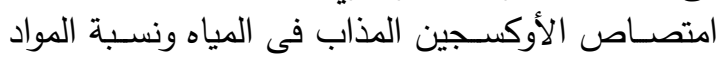

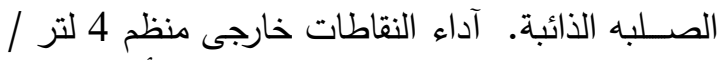

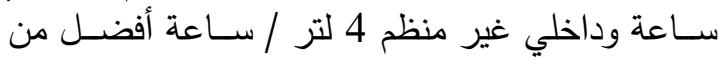

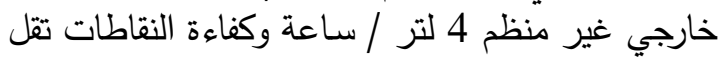

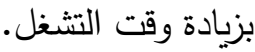

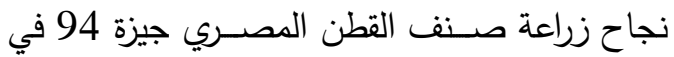

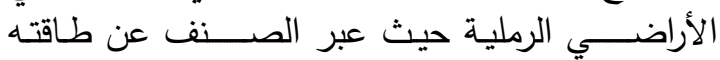

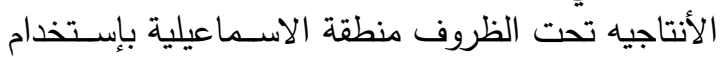

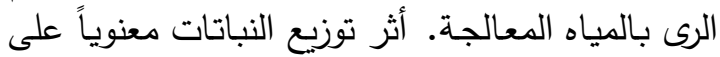

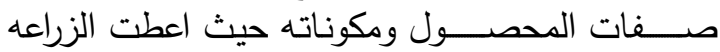

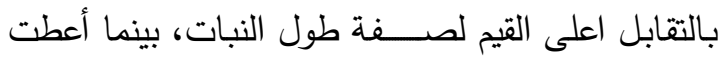
الزراعه بالتبادل أفضل القيم لصفات عدد الافرع الثرب الثريه وعدد اللوز على النبات، ووزن اللفئ اللوزة، ووزن ال 100

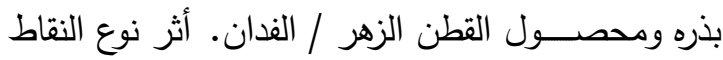

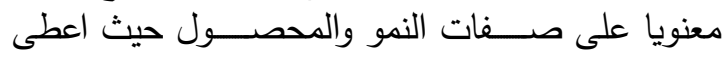

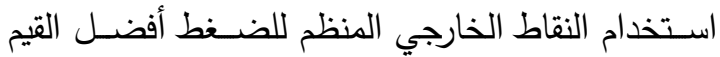

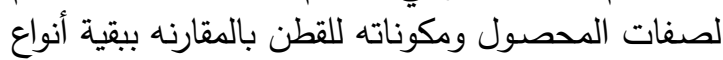

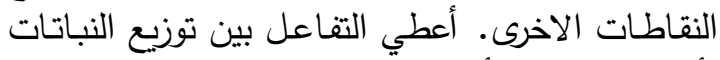

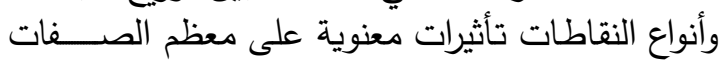

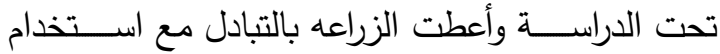

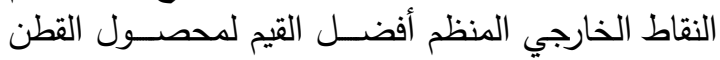

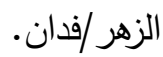

الكلمات المفتاحية: المرشحات الوسطية، مياه الصرف المعالج، الري بالتتقيط، إنتاجية محصول المنات القطن

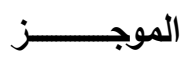

أجريت الدراســــهـ بغابة ســـرابيوم-وزارة الزراعة

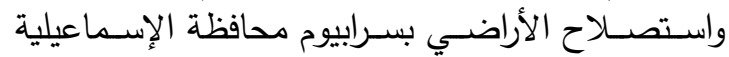

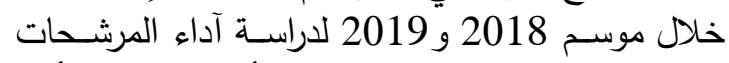

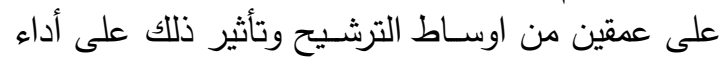

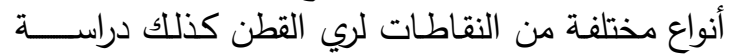

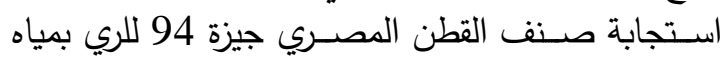

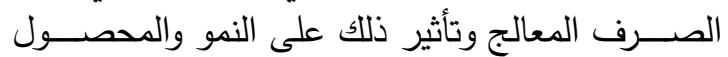

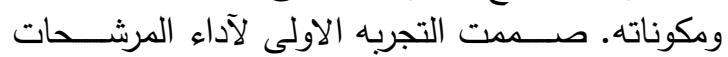

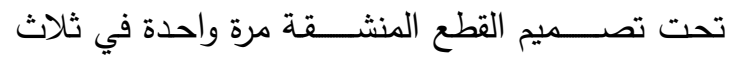

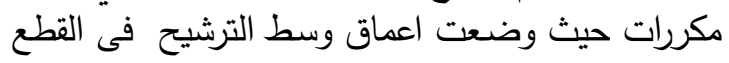

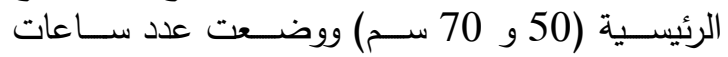

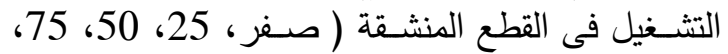

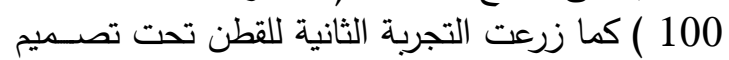

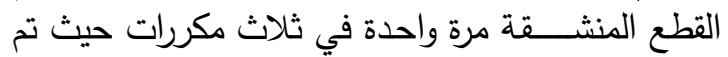

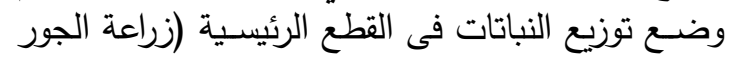

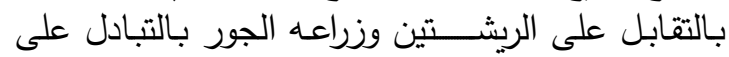
الريشتين ) ووضعت انواع النقاطات في القئ القطع المنشقة

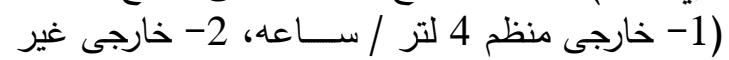

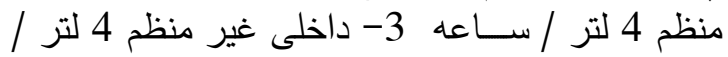

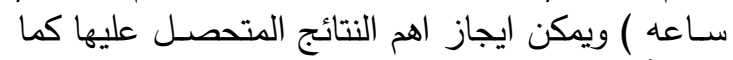

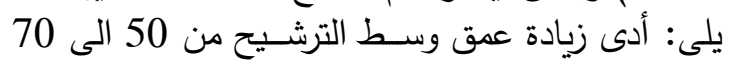

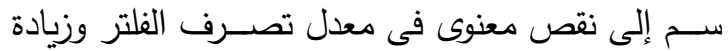

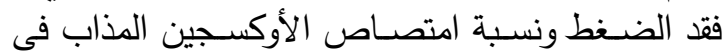

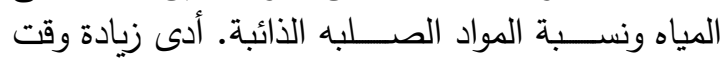

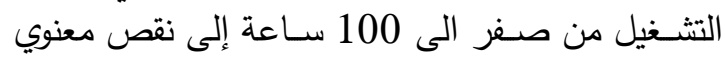

